\section{Does reclaimed water induce morphological changes in midguts of honeybees (Apis mellifera syriaca)?}

\author{
Wael Hananeh, 1 \\ Abd Al-Majeed Al-Ghzawi, ${ }^{2}$ \\ Shahera Zaitoun ${ }^{3}$ \\ 1Department of Pathology and Public \\ Health, 2Department of Plant Production, \\ Jordan University of Science and \\ Technology, Irbid; ${ }^{3}$ Department of Plant \\ Production and Protection, Al-Balqa' \\ Applied University, AI-Salt, Jordan
}

Moreover, drought decreased flowering period for many types of vegetation. In the last few years, because many Beekeepers in Jordan were dealing with drought conditions, they kept their colonies in the areas close to treatment plants and reclaimed water, which is extensively treated wastewater to remove solids and impurities that can be used for irrigation and to other uses. The purpose of this study was to investigate the impact of usage of reclaimed water as the only source of drinking for the honeybee colonies on the bee survival and their midguts environment. This report will be the first report that addresses such impact on the honeybees.

\section{Materials and Methods}

\section{Abstract}

The purpose of this study was to assess the death rate and morphological changes in the midgut of honey worker bees when reclaimed water was the only source of drinking compared with the case when fresh water was the normal source of drinking. Two feeding solutions were implemented: fresh water sugar solution and reclaimed water sugar solution for eight consecutive days. The cages were inspected daily for any deaths of the honeybees. At the end of the experiments, midguts were removed; processed and pathological changes of the midguts were reported. The usage of reclaimed water as a drinking water had negative impacts on the average deaths of the honeybee colonies as well as the morphology of their midguts. To the best of our knowledge, no such studies have been conducted before and this is the first study that addresses the usage of reclaimed water as a sole source drinking water for honeybee colonies.

\section{Introduction}

The digestive tract of the honeybee is divided into foregut, midgut and hindgut. The midgut is only referred to the ventriculus while the hindgut is composed of ileum and rectum. ${ }^{1}$ A chitinous layer that prone the insect to several pathological conditions lines their digestive tract. ${ }^{2}$ The ventricular epithelium produces variable quantities of peritrophic membrane that defend the epithelium from any insult and contributes to utilize the nutrients properly for better bee conditions. ${ }^{3}$

Normally, honeybees collect three substances, which are water, nectar and pollen, to satisfy their nutritional requirements. ${ }^{4}$ Drought in Jordan is commonly responsible for partial or complete failure of many plants.

\section{Study sites}

The experiments were conducted near the main wastewater treatment plant located at Irbid district $\left(32^{\circ} 30^{\prime \prime} \mathrm{N}, 35^{\circ} 59^{\prime \prime} \mathrm{E}\right)$ with altitude of $600 \mathrm{~m}$ for eight consecutive days. Reclaimed water was taken directly from the wastewater treatment plant.

\section{Bee colonies}

The investigations were carried out on workers of the honeybee (Apis mellifera syriaca L.).

\section{Feeding solutions}

Two feeding solutions were implemented as follows. Fresh water sugar solution: one part white sugar was dissolved in one part warm water forming a feeding solution. Reclaimed water sugar solution: one part white sugar was dissolved in one part reclaimed water forming a feeding solution. The reclaimed water was clear and odorless.

\section{Experimental worker cages}

Six special designed small cages resembling the normal hive were produced. Each cage was closed at the bottom with a net (meshes $2 \times 2$ $\mathrm{mm}$ ) and two safety glass windows from both sides to allow watching the bees. These cages ronment with the temperature maintained at $31^{\circ} \mathrm{C}$ and relative humidity at $40 \%$. Two feeding groups were established with 3 cages per group and 100 bees per cage. The first group was supplied with fresh water sugar solution and served as a control while the second group was supplied with reclaimed water sugar solution.

\section{Estimation the number of dead bees}

All cages were inspected daily to confirm the number of dead bees. were kept in a thermostatically controlled envi-
Correspondence: Wael Hananeh, Laboratory of Veterinary Pathology, Department of Pathology and Public Health, Faculty of Veterinary Medicine, Jordan University of Science and Technology, Irbid P.0. Box 3030, Jordan.

Tel.: +962.2720.1000 - Fax: +962.2720 .1081 .

E-mail: whananeh@just.edu.jo

Key words: Honeybees; reclaimed water; midgut; pathology; Jordan.

Acknowledgments: the authors extends deep thanks to the deanship of research at Jordan University of Science and Technology for their financial support (project number 158/2013).

Contributions: the authors contributed equally.

Conflict of interest: the authors declare no potential conflict of interest.

Received for publication: 6 September 2014. Revision received: 23 October 2014. Accepted for publication: 4 November 2014.

This work is licensed under a Creative Commons Attribution NonCommercial 3.0 License (CC BYNC 3.0).

(C) Copyright W. Hananeh et al., 2015

Licensee PAGEPress srl, Italy

Veterinary Science Development 2015; 5:5625

doi:10.4081/vsd.2015.5625

\section{Pathological examination}

After their midguts were removed, they were directly fixed in $10 \%$ formalin for 24 hours. The fixed tissues were processed and embedded routinely. The embedded tissues were cut and stained with Hematoxylin and Eosin (H\&E) stain. The prepared slides were examined blindly by a certified pathologist and the results were recorded.

\section{Statistical analysis}

Differences between treatments means were separated by Chi square-test at $<0.05$ probability level.

\section{Results}

Throughout the entire experiments, no apparent symptoms were seen in the adult honeybees among each group. However, the average of adult honeybee deaths were recorded at the end of the experiments in each group as seen in Table 1. The total number of the average deaths at the end of the first week of the experiment was extremely significantly higher ( $\mathrm{P}$ value is less than 0.0001 ) in the reclaimed water group than the fresh water group. 


\section{Histopathological examinations}

No visible symptoms of diarrhea other than that of adult bee deaths were seen. However, it is worth to mention that the removal of midguts from the group which received reclaimed water was more difficult than their normal counterpart since the tissues were more fragile and easily torn away.

The examined midguts from both groups showed mild to moderate histopathological differences. The midguts from the honeybees when the fresh water was the normal source of drinking showed normal morphology of the midguts (Figure 1) with dilated lumen that contained numerous peritrophic membranes (Figure 1). A few epithelial cells contained perinuclear halo with densely finely granular cytoplasm. The nuclei are rounded with $10 \mu \mathrm{m}$ in diameter. The rhabdorium layer exhibited large rounded bubbles up to $20 \mu \mathrm{m}$ in diameter. Within the lumina of the midguts prominent peritrophic membranes were present. The midguts of the reclaimed water group exhibited several pathological changes. Multifocally, the epithelial lining midguts were swollen and exhibited variably sized irregularly shaped vacuoles that filled most of the cytoplasm making a clear wide halo around the nucleus. Each vacuolated cell have a single small elongated to rounded more basophilic nucleus of 4-7 $\mu \mathrm{m}$ in diameter. Some cells with faded nuclei were present. Multifocally, throughout the examined sections, the epithelial cells lost their cytoplasmic granularity. Their rhabdorium layer exhibited no bubbles except in a few scattered areas. Within their lumina, a few peritrophic membranes were present (Figure 1).

\section{Discussion and Conclusions}

Up to date, no research yet is available to support the fact that reclaimed water has a noticeable negative impact on the survival of the honeybees as well as the morphology of their midguts. This study showed that placing the honeybee colonies near the reclaimed water had negative effects on the survival of the honeybees as well as morphological changes on their midguts. The extreme difference in death rates could be explained because of reclaimed water had a negative impact on the morphology of the midgut epithelial which might affect the antimicrobial properties of the midguts. As a sequel for that effect, honeybees will be prone to several pathological conditions. It has been shown that the antimicrobial effects of the midgut juice hinder the saprophytic bacteria from infecting the midgut. ${ }^{5}$ In most bacterial infections, ingestion of contaminated food will lead to bacterial invasion to the bee body cavity through their intestines and if the protective mechanism of the intes-
Table 1. Average honeybee deaths among fresh water sugar solution group and reclaimed water sugar solution group. The result is significant at $\mathbf{P}<0.05$.

\begin{tabular}{lccc} 
Groups & Dead & Live & Total \\
Fresh water sugar solution & 26 & 74 & 100 \\
Reclaimed water sugar solution & 60 & 40 & 100 \\
\hline Total & 86 & 114 & 200 \\
\hline
\end{tabular}
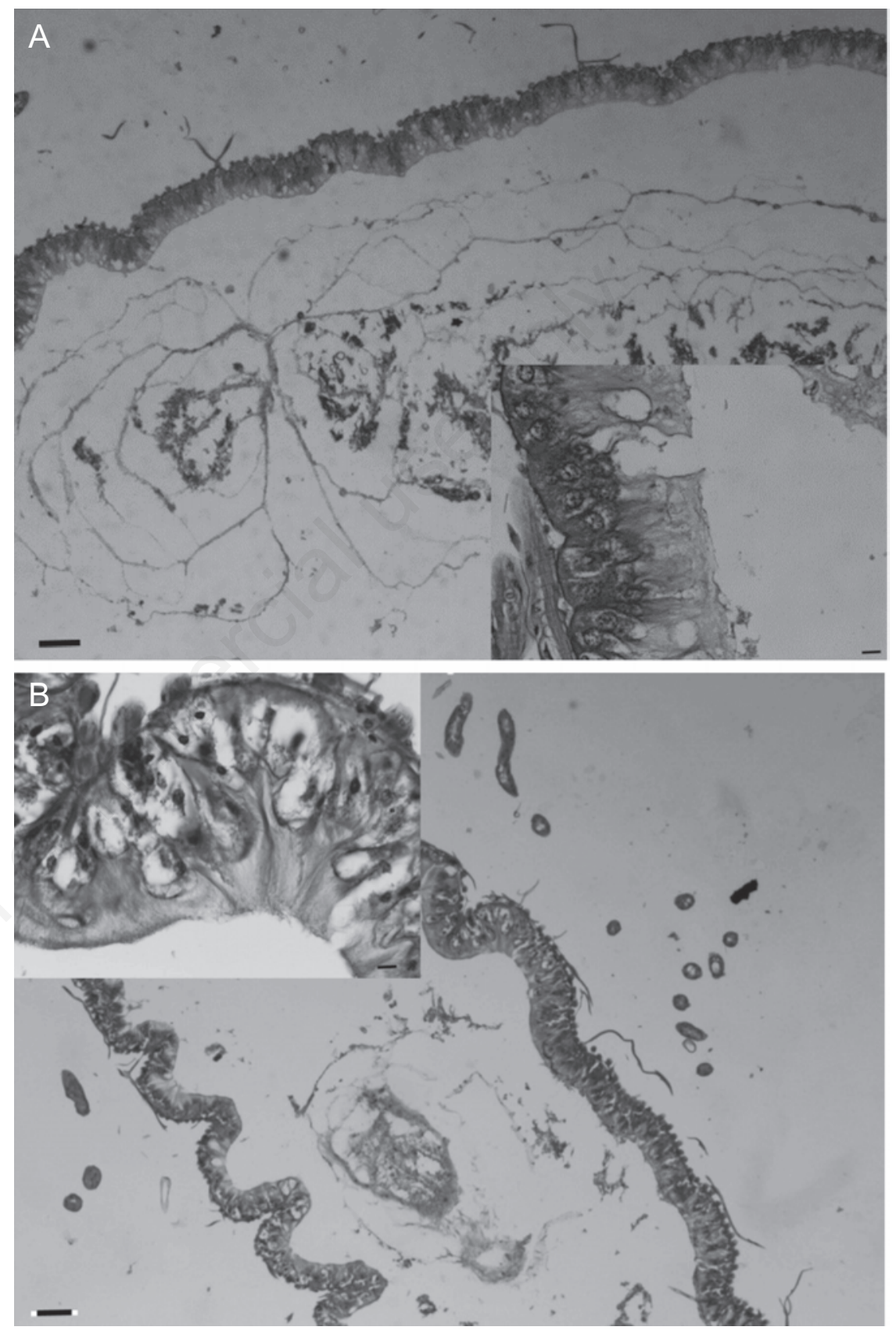

Figure 1. A) Midgut of fresh water sugar solution treated honeybees. Normal morphology of the epithelial lining midgut with prominent peritrophic membranes. Hematoxylin \& Eosin $(\mathrm{H} \& \mathrm{E})$. Bar: $100 \mu \mathrm{m}$. Inset shows normal morphology of the cell cytoplasm and nuclei as well as the merocrine type secretions H\&E. Bar: $10 \mu \mathrm{m}$. B) Midgut of reclaimed water sugar solution treated honeybees. Multifocal cytoplasmic vacuolation and a few peritrophic membranes. H\&E. Bar: $100 \mu \mathrm{m}$. inset shows were swollen epithelial lining midguts that exhibited marked cytoplasmic vacuolation and necrotic nuclei with no merocrine type secretion. H\&E. Bar: $10 \mu \mathrm{m}$. 
tines failed to protect against the invasion, the bacteria will succeed to reach the hemocoel. ${ }^{6}$ The midgut epithelia also produce variable quantities of peritrophic membrane that defend the midgut from any insult and they contribute in proper utilization of the nutrients for better bee conditions. ${ }^{3}$ The reclaimed water might have negative effects on the peritrophic membranes that limited the utilization of nutritional requirements of the honeybees. It is worth to mention that the peritrophic membrane was more prominent in the fresh water group (Figure 1A) than the reclaimed water group (Figure 1B). Presence of bubbles within the rhabdorium layer denoted that the epithelial cells secrete release of enzymes in the form of merocrine type secretion. This type of secretion was reported in normally functioning exocrine glands in the midguts that explain the paucity of these secretions from the affected epithelial cells. ${ }^{2}$

There are many constituents of concern in the reclaimed water that might have major and negative impacts on the honeybee colonies. These factors are high amount of salts, organic and inorganic compounds, nutritional imbalance, pathogens and micro-pollutants. Although, it is believed that efficient reclaimed water treatment would remove the pathogenic microorganisms. ${ }^{7}$ It was reported that several pathogens were resistant to disinfectant treatment and thus can be found in the treated reclaimed water.8-10

Moreover, it had been reported that if the process of reclaimed wastewater was efficient and monitored regularity, no harmful levels of dangerous pollutant would be found even if toxicological analysis carried out. 11 However, several researchers reported a broad range of chemical constituents of the reclaimed water that have negative impacts the homeostasis on some animals. 12,13

The definitive cause or causes of this nega- tive impact is/are undetermined; however, several factors have been reported to cause such morphological changes in the midgut. These factors are infectious processes, non-infectious and/or toxic causes. ${ }^{14,15}$

In conclusion, the usage of reclaimed water as a sole source of drinking water for the honeybee colonies has a negative influence in the honeybee colonies as well as the morphology of their midgut. More work should be carried out on the impact of reclaimed wastewater on the honeybee colonies.

\section{References}

1. Martins GF, Neves CA, Campos LAO, Serrão JE. The regenerative cells during the metamorphosis in the midgut of bees. Micron 2006;37:161-8.

2. Szymaś B, Przybył A. Midgut histological picture of the honeybee (Apis mellifera L.) following consumption of substitute feeds supplemented with feed additives. Nauka Przyroda Technologie 2007;1:4.

3. Szymaś B, Langowska A, KazimierczakBaryczko M. Histological structure of the midgut of honey bees (Apis Mellifera L.) Fed Pollen substitutes fortified with probiotics. J Apicult Sci 2012;56:5-12.

4. Herbert EW. Honey bee nutrition. In: Graham JM, ed. The hive and the honey bee. Carthage: Dadant and Sons; 1999. pp 197-233.

5. Jarosz J. Induction kinetics of immune antibacterial proteins in pupae of Galleria mellonella and Pieris brassicae. Com Biochem Physiol 1993;106B:415-21.

6. Gliński Z, Jarosz J. Infection and immunity in the honey bee Apis mellifera. Apiacta 2001;36:12-24.

7. Toze S. Water reuse and health risks: real vs. perceived. Desalination 2006;187:4151.

8. Meng QS, Gerba CP. Comparative inactivation of enteric adenoviruses, poliovirus and coliphages by ultraviolet irradiation. Water Res 1996;30:2665-8.

9. Rose JB, Dickson LJ, Farrah SR, Carnahan DP. Removal of pathogenic and indicator microorganisms by a full-scale water reclamation facility. Water Res 1996;30:278597.

10. Gennaccaro AL, McLaughlin MR, Quintero-Betancourt W, et al. Infectious Cryptosporidium parvum oocysts in final reclaimed effluent. Appl Environ Microbiol 2003;69:4983-4.

11. Lee GF, Jones-Lee A. Water quality aspects of incidental and enhanced groundwater recharge of domestic and industrial wastewaters: an overview. In: Proc. of Symposium on Effluent Use Management, TPS-93-3, American Water Resource s Association, Bethesda, MD, pp 111-120. 1993.

12. Kime D, Nash JP. Gamete viability as an indicator of reproductive endocrine disruption in fish. Sci Tot Environ 1999;233:123-9.

13. Vos JG, Dybing E, Greim HA, et al. Health effects of endocrine-disrupting chemicals on wildlife with special reference to the European situation. Crit Rev Toxicol 2000;30:71-133.

14. Szymaś B. Ocena wartości odżywczej surogatów pyłku wiatowego dla pszczoły miodnej (Apis mellifera L.). Rocz. AR Pozn., Rozprawy Naukowe pp. 68. 1994.

15. Bielenin I, Ibek Z. Wpływ fluorku sodu na nabłonek jelita środkowego pszczoły miodnej, Apis mellifera L. (Apidae, Hymenoptera). Zeszyty Naukowe AR Kraków 1980;159:49-67. 